\title{
THE ROLE AND POSITION OF CIVIL SOCIETY ORGANISATIONS IN LESOTHO'S DEMOCRATISATION PROCESS
}

\author{
Motlamelle Anthony Kapa and Lira Theko
}

Motlamelle Kapa is a lecturer in the Department of Political and Administrative Studies, National University of Lesotho and a PhD candidate in the Department of Political and International Studies, Rhodes University

Mobile Phone: +270736486312

e-mail: amkapa@yahoo.co.uk

Lira Theko is a Programme Officer at the

Transformation Resource Centre, Maseru,

P O Box 1388 Maseru 100 Lesotho

Tel: +266 22314 463; Fax: +266 22322791

e-mail: democracy@trc.org.ls

\begin{abstract}
This paper assesses the role and position of civil society in Lesotho's democratisation process by interrogating the mandate and functions of civil society organisations from immediately before the transitional elections of 1993 to the recent 2007 polls. While acknowledging the pro-democracy activities of civil society we argue that because of its failure to observe the theoretical civil-political divide its role in democratisation has been ambivalent. While in some cases it has been propitious for democratisation, in others it has tended to undermine the process. We conclude that not only should civil society position itself outside the political realm, although we admit this is not easy to do, but that political society should accept and tolerate civil society as an indispensable partner in the democratisation process.
\end{abstract}

\section{INTRODUCTION}

In this third wave of global democratisation no phenomenon has more vividly captured the imagination of democracy scholars, observers, and activists alike than 'civil society'. What could be more moving than the stories of brave bands of students, writers, artists, pastors, teachers, labourers, and mothers challenging the duplicity, corruption, 
and brutal domination of authoritarian states? Could any sight be more awe-inspiring to democrats than the one they saw in Manila in 1986, when hundreds of thousands of organized and peaceful citizens surged into the streets to reclaim their stolen election and force Ferdinand Marcos out through nonviolent 'people power'?

Diamond 1994, p1

Although the author wrote over a decade ago, the above quotation is instructive for the purpose of this paper, capturing the essence of what has been dubbed the 'civil society argument' (Walzer 1992), the argument that civil society plays a pivotal role in the democratisation process.

The argument has been defended ably by numerous democratic scholars, invoking it in different parts of the world in an attempt to highlight what civil society can do and, indeed, has done to make democratisation possible in what were hitherto authoritarian political systems. One analyst has gone as far as to say: 'No civil society, no democracy' (Fan 2004, p 165).

The main thrust of this argument is that 'a dense network of civil associations promotes stability and effectiveness of a democratic polity through both the effects of association on citizens' "habits of heart" and the ability of associations to mobilize citizens on behalf of public cause' (Foley \& Edwards 1996, p 38).

According to the civil society thesis civic activism can generate democratic regime change' (Yom 2005, p1). Civil society undermines authoritarian rule, fosters a democratic polity, and improves the quality of governance (White 1996, p 185). It is credited with having resisted authoritarian regimes in Latin America and Eastern Europe as well as democratising from below in these parts of the world by putting pressure on these regimes to change (Foley \& Edwards 1996). African civil society has also played a pivotal role in the continent's democratisation. For Gyimah-Boadi (1996, p 118), 'among the forces that dislodged entrenched authoritarianism in Africa and brought about the beginnings of formal democracy in the early 1990s, the continent's nascent civil societies were in the forefront'.

In line with the civil society thesis this paper maintains that civil society has a positive role to play in the process of democratisation. We note, however, that the validity of the thesis should not be exaggerated: there are cases in which civil society has not been able to produce democratic outcomes. Yom (2005, p 1), for instance, contends that the argument for civil society does not hold in the Arab world, arguing that the expansion of civil society has not been able to democratise the political systems there, but has, instead, been used by autocratic rulers as a strategy to perpetuate repression.

Our approach is circumspect, leaving room for guarded optimism and cautious pessimism. It is an approach that allows us to appreciate both successes 
and failures in the nebulous civil society-democracy nexus. We agree with White (1996, pp 192-207) that the ability of civil society to promote democratisation as a process and democracy as a preferred system of government is dependent on the nature of the state (democratic or authoritarian), the level of the elite's commitment to democracy - both within civil society itself and within the state, and the level of economic development and industrialisation.

With this in mind the task of this paper is to answer the following questions: What has been the role and position of civil society in Lesotho's democratisation in general and the 2007 electoral process in particular? What contribution has civil society made to the management of pre-election and post-election conflict? It is imperative to conceptualise democratisation and civil society as we do below.

\section{CONCEPTUALISING CIVIL SOCIETY AND DEMOCRATISATION}

The concepts of civil society and democratisation are key to this paper, with the latter less problematic than the former. Democratisation has been defined as ' a long process that takes several generations to achieve; it begins with political challenges to authoritarian regimes, advances through political struggles for liberalisation, requires the installation of freely elected government, and concludes when democratic rules have been firmly institutionalized' (Bratton \& Van de Walle 1997, p 194). There is consensus in the literature that the process of democratisation began in the late 1980s and early 1990s: the period widely referred to as the 'Third Wave of Democratisation'. Almost all African countries have gone through at least the four stages reflected in the definition above.

Civil society is an important ingredient in a pluralist democracy but, as with many concepts in the social sciences, that of civil society is nebulous and elusive and it has been defined in different ways depending on the theoretical perspectives, circumstances, and contexts in which it is used. Its emergence in the literature of political theory may be traced as far back as the works of Enlightenment philosophers such as Thomas Hobbes and John Locke, where civil society was equated with the state.

For these theoreticians civil society was the result of humankind's transition from the inhospitable state of nature - a hypothetical political condition in which there was no common authority to regulate human behaviour and settle human disputes. It meant specifically 'those who are united into one body and have a common established law and judicature to appeal to, with authority to decide controversies between them and punish offenders' (Strauss \& Cropsey 1972, p 479).

With time and developments in political theorisation civil society took on new connotations. It now "consists of those groups which are "above" the personal realm of the family but "beneath" the state' (Hague, Harrop \& Breslin 1998, p 86). 
For Heywood (2002, p 29) civil society refers to the 'realm of autonomous groups and associations, a private sphere independent from public authority', concepts which are too broad, failing to define the groups and just how civil society relates to the state and the market. The emphasis appears to be on the autonomy or even independence of civil society from the state, yet the boundaries between the two are blurred.

Pointing to the definitional problems shrouding the concept Foley \& Edwards (1996, p 38) aptly observe that it is not clear whether civil society includes business or the market. They warn that it is difficult to 'distinguish between political associations per se and the activities of groups in civil society ... in pursuit of political goals'. 'Just when does the "civil" become the political?' they ask (Foley \& Edwards 1996, p 39). A more elaborate concept of the term is provided by the London School of Economics (LSE), which states that it

refers to the arena of uncoerced collective action around shared interests, purpose and values. In theory, its institutional forms are distinct from those of the state, family and market, though in practice, the boundaries between state, civil society, and market are complex, blurred and negotiated. Civil society commonly embraces a diversity of spaces, actors and institutional forms varying in their degree of formality, autonomy and power. Civil societies are often populated by organisations such as registered charities, development nongovernmental organisations, community groups, women's organisations, faith-based organisations, professional associations, trade unions, self-help groups, social movements, business associations, coalitions and advocacy groups.

LSE www.lse.ac.uk

The LSE definition is useful in that it stresses key features of civil society, namely, uncoerced or voluntary collectivity, theoretical distinction from the state and market, yet with blurred and contested boundaries, and the diversity of the groups that form it. But the definition leaves out a very important group - the private mass media, whose role in the process of democratisation in Lesotho has been so vital.

However, bearing in mind this omission, for the purpose of this paper we adopt the LSE definition. Thus, we conceive of civil society as consisting of all the social formations whose business it is to promote, sustain, and even defend the democratisation process. These, for the purpose of this paper, are the Lesotho Council of Non-governmental Organisations (an umbrella body of non-state organisations), the trade union movement, the mass media, and the churches. 
It is crucial to state from the onset that the role of each of the social groups comprising civil society differs from one context to another; some will and have been more effective than others in democratisation at different stages of the process. But what specific democratic roles does civil society play in political systems? We look more closely at these below.

\section{THE DEMOCRATIC MANDATE AND FUNCTIONS OF CIVIL SOCIETY}

Civil society performs numerous democratic functions. According to Huntington (1984, p 203), civil society 'provides the basis for the control of state power, hence for the control of the state by society'. Without civil society, Huntington continues, 'societies are likely to be dominated by centralized power apparatus - an absolute monarchy, an oriental despotism, or an authoritarianism or totalitarian dictatorship'. In the same vein White (1996, p 185) submits that 'civil society can alter the balance of power between the state and society in favour of the other, thereby contributing to the kind of balanced opposition held to be characteristic of developed democratic regimes'. This, in his view, implies weakening state power while at the same time increasing the ability of civil society to prevent it being governed against its will. Diamond (1994) sets out the democratic mandate and functions of civil society, maintaining that it:

- contains the power of democratic governments, checks their potential abuses and violation of the law, and subjects them to public scrutiny to prevent corruption - a free, robust, and inquisitive press and civic groups are instrumental in this regard;

- stimulates political participation and provides civic education, instils in citizens vital democratic values such as tolerance, moderation, willingness to compromise, and respect for opposing views;

- provides channels for articulating and representing interests, especially those of traditionally excluded groups such as women and racial and ethnic minorities.

- creates a wide range of cross-cutting interests, thereby mitigating political conflict;

- carries out non-partisan election monitoring to deter fraud, enhance voter confidence, affirm the legitimacy of election results and demonstrate an opposition victory despite government fraud.

- disseminates information to citizens to help them defend and pursue their interests and values. 
In order to carry out these functions effectively civil society must establish for itself a firm position that is distinct from that of political society - the state and political parties, the main object of which is to acquire political power. It must maintain its autonomy. This balance is very difficult to strike, especially in the case of Africa in general, and Lesotho in particular, for two main reasons. One is that civil society membership and leadership is made up of human beings with their own political interests. Thus any discourse on civil society should not commit the error of reifying and treating civil society as if it has a life distinct from that of its members. Secondly, as we have indicated in our conceptualisation, civil societystate boundaries are contested and blurred and the state (especially in the context of Africa) has always attempted to encroach on civil society autonomy.

In his lucid analysis of civil society-state relations in contemporary Africa, Mamdani (1990) chronicles how the post-colonial state succeeded in defeating popular movements by various means, including the use of brute military force against radical movements; co-optation of some civil society leaders into the state system; legalisation of the most important organisations in order to bring them under the scrutiny of the state and undermine their autonomy and popular accountability; criminalisation of organisations unfriendly to the state; and splitting leaders from the rank and file of the popular movements. But the state is not the only guilty party in failing to observe the boundaries between itself and civil society. In the pursuit of personal rather than organisational interests members of civil society also cross the civil-political divide, if, indeed, one exists.

Ideally a democratic civil society would be a positive ingredient of democratisation, but the attempts by civil society to promote democracy have been circumscribed by myriad problems. Gyimah-Boadi (1996, pp 118-25) notes that civil society remains too weak to promote democracy effectively. The weakness emanates from a lack of resources, state repression, ethno-regional and religious cleavages and conflict, and cooption and banning by the state. What then, in the light of this broader context, has been the position and role of Lesotho's civil society in the country's democratisation? Has civil society lived up to its self-assigned functions since the country began to move towards democracy in the early 1990s? The following section tackles these questions.

\section{THE ROLE AND POSITION OF LESOTHO'S CIVIL SOCIETY IN DEMOCRATISATION}

\section{Contextual Framework}

Since its genesis Lesotho's civil society has not observed the 'civil-political' divide, so its role in the country's democratisation has been ambivalent: in some cases it 
has been propitious for democratisation (especially towards the end of military rule and the early days of the Basutoland Congress Party - $\mathrm{BCP}$-administration), while in other cases it simply appeared to condone the state's undemocratic practices (as was the case towards the end of the $\mathrm{BCP}^{\prime}$ s first term in government and, more recently, the present administration of the Lesotho Congress for Democracy - LCD).

This was the result of the convergence of political interests between civil society leaders and the governing elite, or simply the result of cooption of the leaders by the state elites. The emergence of organisations comprising civil society in Lesotho, as indeed has been the case in colonial Africa, far predates independence. But from the outset these organisations were aligned to the two main political parties: a problem which continues to bedevil civil society.

The first labour unions, the Basutoland Federation of Labour (BFL) and the Lesotho Council of Workers (LCW), were closely aligned to the country's then biggest parties, the $\mathrm{BCP}$ and the BNP respectively. The secretary general of the former was Shakhane Mokhehle, brother of the then BCP leader, Ntsu Mokhehle, while the latter was led by John Molai Lephole, son-in-law of the BNP leader, Chief Leabua Jonathan (Southall 1984, p 97). Instead of promoting and protecting the workers' interests the unions were used to fight the political battles of these two parties after independence in October 1966.

The main churches, too, were closely aligned to the two parties: the Lesotho Evangelical Church (LEC) to the BCP and the Roman Catholic Church (RCC) to the BNP. These divisions were replicated in the activities of the print media owned by these churches. The LEC- owned Leselinyana la Lesotho was pro-BCP, while the RCC's Moeletsi oa Basotho was pro-BNP.

When the third wave of democratisation began in the early 1990s Lesotho's then military junta was under tremendous pressure both from within the country and outside it to return the country to democratic civilian rule. At this time civil society became a powerful force, pressing the regime for democratic change. At a conference organised by the Lesotho Council of Non-Governmental Organisations (LCN) held from 29 to 31 October 1991 on 'National Unity and Democratic Rule' in Lesotho civil society organisations were unequivocal about their commitment to democratisation.

A robust resolution emphasised that civil society's role was 'to facilitate an opportunity for the nation to impact on the process of transition to democratic rule promised by the military government and to guard against either the government itself or anyone reversing it' [author's emphasis] (LCN 1991, p1).

The conference called on the military government to honour its commitment to return the country to civilian rule by organising free and fair elections and castigated the government for impeding the democratisation process by retaining 
the then Order No 4 of 1986 which banned parties and party political activities and called on the government to announce the election date and to publicise the electoral law and the office or commission which would run the election.

This was a positive move towards democratisation and, indeed, the military did organise elections, which were held in March 1993 and gave the BCP a landslide victory.

Hardly two years after the 1993 elections, however, there was armed conflict within the Lesotho Defence Force (LDF), leading to faction fighting between the army's two barracks, the Ratjomose and Makoanyane. In the midst of these military skirmishes civil society established a 'Crisis Committee' in an attempt to resolve the crisis. The committee petitioned the then prime minister, Ntsu Mokhehle, and the commander of the LDF. Selinyane (1997, p 41) submits that during the 1994 military crisis 'the NGO coalition not only deplored the intramilitary skirmishes and chastised opportunistic politicians for fanning suspicions and cleavages in the army but also lambasted the government for its regular taunts against all sectors of the public service...' As a result of this intervention the government instituted a commission of inquiry to investigate the causes of the crisis (Sello 1998, pp 3-4).

In August 1994 King Letsie III dissolved Parliament and ousted the BCP government because it refused to reinstate his father, King Moshoeshoe II, who had been dethroned by the military regime. Since independence the king had had problems with 'his' governments relating to his role as a constitutional monarch - he harboured an ambition to become executive monarch (Machobane 1990, p 276). As a result he was sent into exile numerous times both by the BNP and during the period of military rule, until he was dethroned in 1990. He fought to be reinstated but his calls went unheeded, even by the new BCP government.

Civil society mobilised the population to embark on a series of non-violent activities to reverse the 'palace coup' and also brokered negotiations between the belligerent parties. The activities included nationwide stayaways, the object of which was to avoid violence and bloodshed, restore democracy, and call for national dialogue (Sello 1998, p 9). The campaign proved successful and the government was reinstated with the help of a Southern African Development Community (SADC) mediation team comprising the presidents of Botswana, South Africa, and Zimbabwe.

The reinstatement of the $\mathrm{BCP}$ government alone, however, did not bring political stability and civil society, led by the $\mathrm{LCN}$, organised a national conference of representatives of various sectors of society, including the Cabinet, the National Assembly, the judiciary, opposition parties, academics, students, the churches, chiefs, trade unions, the youth, media, farmers and NGOs (Report on the National Conference 1995). The object of the conference was to afford other sectors of society 
the opportunity to contribute to the process of bringing about stability and to influence the government to hear the views of others, particularly the opposition parties (Report on the National Conference 1995).

The outcome of the conference was a number of resolutions, including, for the purpose of this paper, one calling for a review of the first-past-the-post (FPTP) electoral model and the establishment of an Independent Electoral Commission (IEC) (Report on the National Conference 1995, p 66). The IEC was established before the 1998 election and the new mixed member proportional (MMP) system was adopted prior to the 2002 election.

The LCN has been involved in attempts to resolve post-election ${ }^{1}$ conflict through various forums. After the disturbances in 1998, which almost led to civil war, it organised a Special Forum on Lesotho's 1998 General Elections from 2-3 December of that year, the objective of which was to promote debate and discussion as well as knowledge-sharing about governance issues affecting the Basotho (LCN 1998). The event was attended by academics from the National University of Lesotho and pro-democracy activists.

Lesotho's civil society has also been involved in fighting for the rights of some of its members, especially the workers. The implementation of the bilateral water transfer treaty, the Lesotho Highlands Water Project (LHWP) between the Lesotho military government and South Africa in 1987 led to the unionisation of the project's workforce. According to Selinyane (1997, pp 32-33) this was the result of the difficult working conditions and the recruitment of retrenched Basotho mineworkers following the 1987 strike in the South African mines. The workers embarked on a series of strikes over what they saw as low wages and poor working conditions.

The unionisation of the LHWP workforce was emulated in 1990 by the country's teachers, who formed the Lesotho Teachers' Trade Union (LTTU), which the military government refused to recognise. Instead, the government instigated the formation of a friendly organisation, the Lesotho Association of Teachers, which was largely comprised of the headmasters of primary and high schools. (Interview, Vuyani Tyhali, Secretary General of the Lesotho Teachers' Trade Union 2008). ${ }^{2}$ Despite government's refusal to recognise the LTTU the union organised groups such as the National University of Lesotho Academic Staff Association, and National University of Lesotho students supported the striking unions and began to call for the restoration of multiparty democracy (Selinyane 1997, p 32).

1 Lesotho does not have a history of serious pre-election conflict; conflict often erupts after elections, the most serious being that of 1998 .

2 This development is reminiscent of the action of the BNP government in forming its own alternative union to the BFL, as indicated above. 
The significance of these actions is that the unions' response clearly transcended bread and butter issues, including, as they did, specific demands for regime change. This was a logical move, since the regime had banned all forms of political activism through Order No 4 of 1986. The unions became the platform for those seeking political change. The military and the $\mathrm{BCP}$ government respectively responded to the strikes by putting them down brutally and enforcing a no-workno-pay ruling.

Although the military ultimately succumbed to the pressure and handed over power to the BCP after the 1993 election it should not be assumed that civil society was a united force fighting for the political liberation of Lesotho. In fact, it was still divided along party political lines. At that point even the labour movement was divided and failed to form a unified federation. In February 1998, however, after a meeting, nine trades unions agreed to form a federation, the Congress of Lesotho Trade Unions (Coletu), which, in solidarity with the Lesotho Clothing and Allied Union workers (Lecawu), condemned the killing by the police of one woman and the injury of 46 others (Matlosa 1997, p 105) Furthermore, the individual unions had their own internal problems such as opportunism, power struggles, financial corruption, and bribe taking (Matlosa 1997, p 105).

The advent of multiparty democracy in 1993 raised the expectations of civil society and the general citizens about the opening of political space. These expectations were, however, dashed by several negative actions and the attitude of the state towards civil society, in particular the trade union sector. During this period there was massive unionisation within both the public and the private sectors. For the first time in the country's history civil servants formed their own trade union - the Lesotho Union of Public Employees (LUPE). The BCP government swiftly passed two pieces of legislation - the 1995 Public Service Act and the 1995 Education Act - both of which effectively proscribed unionisation in the public service and the teaching service, tarnishing the new regime's democratic credentials (Selinyane 1997, p 40).

The government also used the police to clamp down on strikes by Lesotho Telecommunication Corporation workers, LHWP workers, teachers belonging to the banned LTTU, and textile and clothing-factory workers. In some instances extreme violence was used, leading to the deaths of unarmed workers. In the case of the LHWP staff strike, for example, several workers were killed and the deputy prime minister and the minister responsible for the police (Lesotho's current prime minister, Pakalitha Mosisili, publicly commended the police on 'a marvellous job' (Selinyane 1997, p 40).

Selinyane (1997, p 42) notes that the LCN, displaying double standards, refused to intervene in these strikes and the resultant state brutality, its new leaders arguing that these were matters for the Democracy and Human Rights Com- 
mission. The reason for this stand was that the leaders were motivated by their affiliation to and sympathy for the BCP government. To intervene, the leaders argued, would mean 'destabilizing our government' (Selinyane 1997, p 42). The LCN insisted that its function was to 'keep the lines of communication with government open leaving the politics and political questions to its politicallyoriented affiliates' (Selinyane 1997, p 42).

The LCN also failed to act in a subsequent case of police violence against textile and clothing factory workers in which two women were shot dead and many others seriously injured in November 2003 (US Department of State 2003), confirming its clear alignment with the government. Did the situation change during the 2007 general elections? What role did civil society play in these elections? The next section deals with these questions.

\section{CIVIL SOCIETY AND THE 2007 ELECTIONS}

Civil society appeared unwilling to respect the theoretical civil-political divide even during the 2007 election. When the king dissolved Parliament, as provided for in the Constitution, and announced a snap election to be held in February all stakeholders were taken by surprise. Nonetheless civil society was quick to adapt and ready itself for the election. Although polarised along political party lines, as were other organisations, the mass media played a crucial role in terms of mobilising the population to register and vote. Several radio stations provided special phone-in programmes allowing public debate on a range of election-related issues, while at the same time displaying loyalty to the main political parties. The erstwhile anti-government Moafrika FM did a swift turnabout, supporting the governing LCD after it split and the All Basotho Convention (ABC) was formed by the former Minister of Communications Science and Technology, Thomas Motsoahae Thabane, and 17 former LCD members of Parliament.

The station received favours from the government, including state advertisements and controversial airtime via one of the country's telecommunications companies. These were denied to 'unfriendly' stations such as the newly established Harvest FM, People's Choice FM, Catholic Radio, and newspapers, notably the popular Public Eye. In addition, the government harassed Harvest FM and People's Choice FM in various ways, including temporary closures and the arrest of prominent journalist on allegations of broadcasting information considered by the government to be causing political instability and inciting a coup. Some of these cases are still before the courts. ${ }^{3}$

3 The allegations about harassment of media personnel were widely reported in both the electronic and print media, see, eg, Motonotsi 2007. 
The stations provided special programmes for opposition leaders and sympathisers and covered party rallies, the vote count, and the announcement of results. However, since the February general election media-state relations have continued to be adversarial and the media have not been neutral in their reporting.

The 2007 election was contested on the basis of political party alliances, a new phenomenon in the country's politics. This in and of itself is not a problem, but it raised queries about the way the IEC allocated the proportional representation seats. This led to the current standoff between the government and five opposition parties. In the midst of this debacle the LCN, in partnership with EISA, organised a regional conference on Lesotho's post-election crisis on 25-27 September, involving all the key stakeholders including all political parties, the civil-society fraternity and academics, in an attempt to resolve the problem through debate and discussion. Thus far no solution has been reached and the possibility of one being found appears remote because the government and the opposition are far apart: the former insisting that the courts must rule on the matter while the latter would prefer a political solution reached through negotiations. This indicates that civil society cannot do much to resolve similar problems if the concerned parties lack the political will and the culture of negotiation.

\section{CONCLUSION AND RECOMMENDATIONS}

We cannot claim to have covered comprehensively all organisations comprising Lesotho's civil society nor what they have done since the start of the third wave of democratisation but we have highlighted the positive role Lesotho's civil society has played in the country's democratisation process since the early 1990s. Civil society put pressure on the military government to return Lesotho to civilian rule prior to the 1993 elections; organised two national conferences, in 1991 and 1995, which resulted in the establishment of the IEC and the adoption of the MMP electoral model; challenged the king to reinstate the elected BCP government following the 1994 'palace coup'; mobilised the population to stage stayaways and other non-violent protests against the king; petitioned the prime minister and the commander of the LDF to resolve the 1994 army crisis; and organised conferences to discuss post-election conflict. These achievements notwithstanding, we have argued that by aligning itself closely with political parties and the government civil society has not been able to observe the theoretical civil-political divide. As a result its role in the democratisation project has been ambivalent.

Continuing to build on the contribution it has made to Lesotho's democratisation process civil society would need to reposition itself outside political society. This is, admittedly, not an easy position to take, for it is made up of people with their own political affiliations, but it is not impossible to achieve. 
Civil society, especially the mass media, should be neutral and should avoid bias either in favour of or against the government and the opposition. The LCN should not hesitate to criticise both government and opposition parties constructively.

Political society (both government and opposition) too should accept and tolerate civil society as a partner in democratisation. We are aware, however, that these recommendations are not easy to adopt, given that Lesotho's political economy is characterised by a weak economic base, making it difficult for its citizens to earn a decent living outside the state and leading to incessant conflict and polarisation across all social formations. But we strongly believe in human agency and that nothing is impossible provided all the actors are committed to consolidating Lesotho's democracy.

\section{- REFERENCES}

Bratton, M \& N Van de Walle. 1997. Democratic Experiments in Africa: Regime Transitions in Comparative Perspective. Cambridge: Cambridge University Press.

Diamond, L. 1994. 'Towards Democratic Consolidation'. Journal of Democracy 5(3). Fan, Y. 2004. 'Taiwan: No Civil Society, No Democracy'. In M Alagappa (ed). Civil

Society and Political Change in Asia: Expanding and Contracting Democratic Space. Stanford: Stanford University Press.

Foley, W M \& B Edwards. 1996. 'The Paradox of Civil Society'. Journal of Democracy 7(3).

Gyimah-Boadi, E. 1996. 'Civil Society in Africa'. Journal of Democracy 7(2).

Huntington, S P. 1984. 'Will More Countries Become Democratic?' Political Science Review 99(2).

Hague, R, M Harrop and S Breslin. 1998. Political Science: A Comparative Introduction. New York: Macmillan.

Heywood, A. 2002. Politics. Houndsmills: Palgrave.

Lesotho Council of Non-Governmental Orgainisations. 1991. Resolutions of the National Conference on National Unity and Democratic Rule, Lesotho Sun Hotel, 29-31 October 1991.

London School of Economics and Political Science <www.lse.ac.uk/ collections / CCS/what_is_civil_society.htm>

Machobane, L B B J. 1990. Government and Change in Lesotho, 1800-1966: A Study of Political Institutions. Houndsmills: Macmillan.

Mamdani, M. 1990. 'State and Civil Society in Contemporary Africa: Reconceptuaizing the Birth of State Nationalism and the Defeat of Popular Movements'. Africa Development XV (3\&4). 
Matlosa, K. 1997. 'Political Instability and Elections: A Case Study of Lesotho'. Lesotho Social Sciences Review 3(2).

Motonotsi, M. 2007. 'Media under attack: journalists threatened from everywhere'. Public Eye 11(6), 9-15, February.

Sekatle, P. 1997. 'The establishment of Lesotho Congress for Democracy: Implications for the 1998 general elections'. Lesotho Social Science Review 3(2)

Selinyane, N P. 1997. 'Civil Society and Electoral Politics and the Retrieval of Democracy in Lesotho'. Lesotho Social Sciences Review 3(2).

Sello, N C. 1998. 'A Decade of Civil Society's Peace, Reconciliation and Conflict Resolution in a Democratic Dispensation'. Paper Presented at a Special Forum on Lesotho's 1998 General Elections, Maseru Sun Hotel, 2-3 December.

Southall, R. 1984. 'Trade Unions and Internal Working Class in Lesotho'. South African Labour Bulletin 10(3).

Strauss, L \& J Cropsey. 1987. History of Political Philosophy. Chicago: University of Chicago Press.

Tyhali, V. 2008. Interview conducted at the National University of Lesotho, Roma campus, 13 January.

United States Department of State. 2004. 'Lesotho Country Report on Human Rights Practices 2003'. Released by the Bureau of Democracy, Human Rights, and Labour, February. Available from: www.state.gov/g/dr/hrrpt/2003/ 27734.htm.

Walzer, M. 1992. 'The Civil Society Argument'. In C Mouffe (ed). Dimensions of Radical Democracy: Pluralism, Citizenship, Community. London: Verso.

White, G. 1996. 'Civil Society, Democratisation and Development'. In R Luckham \& GWhite. Democratisation in the South: The Jagged Wave. Manchester: Manchester University Press.

Yom, S I. 2005. 'Civil Society and Democratisation in the Arab World'. The Middle East Review of International Affairs 9(4). 